from the fact that in the latter cases the extent of the homogeneity range includes compositions such as $\mathrm{Au}_{3} \mathrm{X}$ and $\mathrm{Au}_{2} \mathrm{X}$ which are important for the forma- tion of long range ordered structures, while the theoretical maximum for a trivalent solute is only 20 atomic per cent.

\title{
References
}

1 W. Hume-Rothery, G. W. Mabbott and K. M. ChannelEvans, Phil. Trans. Roy. Soc., [A], 1934, 233, 1

2 A. B. Pippard, Proc. Roy. Soc., $[A], 1954,224$, (1157), 273

3 M. H. Cohen and V. Heine, Adv. Phys., 1958, 7, (28), 395

4 E. Raub and A. Engel, Z. Metallkunde, 1946, 37, 76

5 W. G. Witteman, A. L. Giorgi and D. T. Vier, F. Phys. Chem., 1960, 64, (4), 434

6 C. S. Barrett and T. B. Massalski, "The Structure of Metals", McGraw-Hill, New York and London, 1967

7 S. L. Altmann, C. A. Coulson and W. Hume-Rothery, Proc. Roy. Soc., $[A], 1957,240,(1221), 145$
8 S. E. R. Hiscocks and W. Hume-Rothery, Proc. Roy. Soc, $[A], 1964,282,(1390), 318$

9 V. G. Rivlin, W. Hume-Rothery and B. Ryder, Acta Metall., 1962, 10, (12), 1143; 1963, 11, (5), 488

10 R. P. Elliott, "The Constitution of Binary Alloys", First Suppl., McGraw-Hill, New York and London, 1965 , pp. 107,108

The second part of Professor Raynor's review, dealing with the formation of compounds of gold with other metals, will be published in the April issue of Gold Bulletin.

\section{Gold Concentration by Flotation}

Reference was made recently to improvements to standard gold extraction processes on the Witwatersrand associated with the recovery or concentration of uranium or pyrite (Gold Bulletin, 1975, 8, (3), 85). A further development of this type was described by S. K. de Kok at a symposium organised by the South African Institute of Mining and Metallurgy in September last year.

The Anglo-Transvaal Consolidated Investment Company recovers pyrite on a large scale from its gold ores by flotation before cyanide treatment. The gold associated with the pyrite is recovered from the concentrate by cyaniding in a separate circuit, and this has resulted in a marked decrease in overall residue values at much coarser grinds than were previously possible. In the course of the development work on the pyrite flotation, it was observed that using a frother plus a dithiophosphate at high $\mathrm{pHs}$, and in the absence of xanthates and activators such as copper sulphate, a high proportion (65 to 75 per cent) of the gold in the ore floated selectively in a concentrate con- stituting only about 2 per cent of the weight of the feed.

This selective separation of gold from pyrite is now being applied in the cleaning up of gravity concentrates on two mines of the Group. Flotation concentrates directly suitable for smelting are obtained, and amalgamation and retorting have been dispensed with.

The author concludes that flotation is destined to play a larger role in future recovery of gold. Its application to gravity concentrates is immediately attractive, since the bulk of the gold can be collected in these concentrates, without recourse to fine grinding, and the low grade fraction containing probably 10 to 20 per cent of the gold in about 90 per cent of the original ore treated with cyanide, with savings in both capital and working costs. Its application as the primary means of removing gold from the pulp still presents problems, however, since experience has shown that reagents so far found effective in floating gold tend to inhibit cyanidation, so that gold recovery from flotation tailings is more difficult.

Gold being floated from a gravity concentrate in a lab. oratory flotation cell at the Village Main Reef Gold Mining Company (1934) Limited in Johannesburg, using a frother and a flotation agent containing dithiophosphates. The flotation concentrate is smelted direetly so that amalgamation and retorting are eliminated

Photograph by J. Taylor

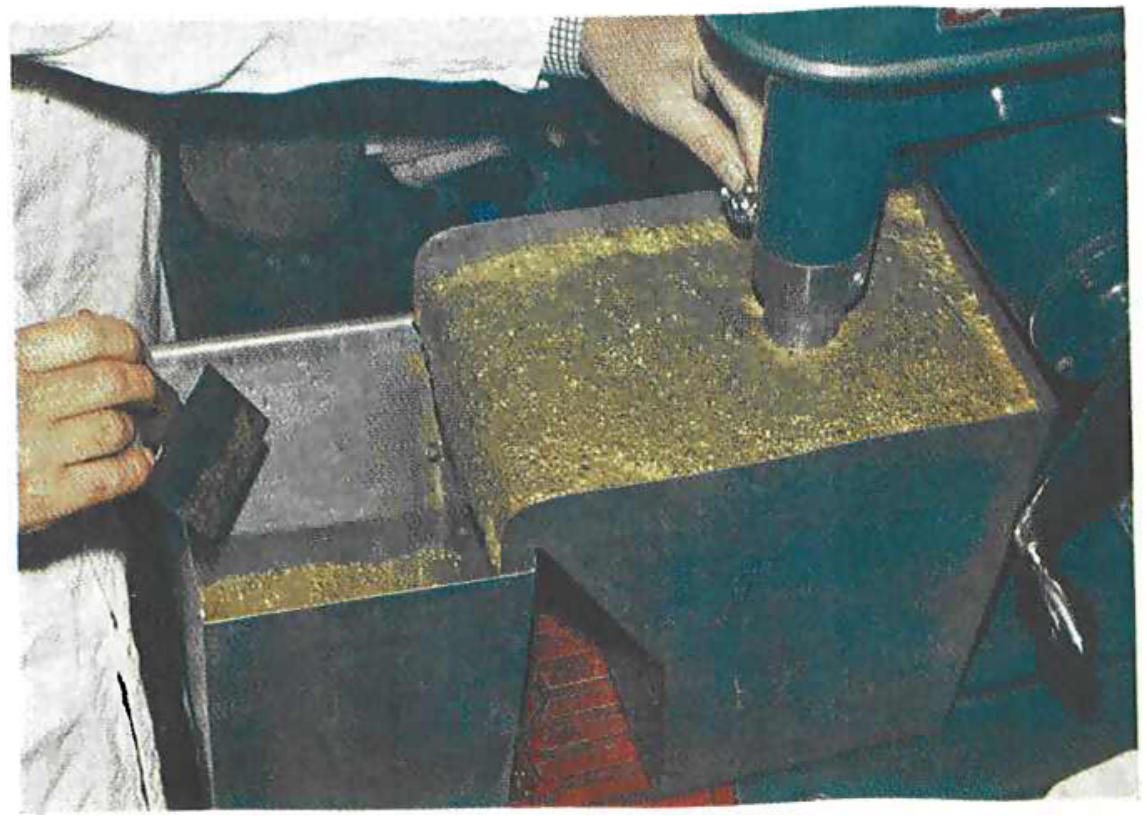

